\title{
Plio-Pleistocene rapid uplift process of the Nepal Himalaya revealed from fission-track ages
}

\author{
Kazunori Arita†* and Hiroto Ohirał \\ † Department of Earth and Planetary Sciences, Graduate School of Science, Hokkaido University, Sapporo, 060-0810, JAPAN \\ ¥ Department of Geosciences, Interdisciplinary Faculty of Science and Technology, Shimane University, Matsue, 690-8504, JAPAN \\ * To whom correspondence should be addressed. E-mail: arita@ep.sci.hokudai.ac.jp
}

The Nepal Himalaya has been a fold-and-thrust belt in the northern margin of the Indian continent after the India-Eurasia collision during the Eocene time. It is characterized by a series of foreland-propagating thrusts with an out-of-sequence thrust in the northern part of the Lesser Himalaya. Among these thrusts which splay of from a major mid-crustal subhorizontal décollement (Main Detachment Fault or Main Himalayan Thrust), the Main Central Thrust zone, along which the Higher Himalayan crystallines in the north are thrust over the Lesser Himalayan sediments in the south, is the most important one in the Himalayan tectonic evolution (Schelling and Arita 1991, Zhao et al. 1993).

Abundant geological and geomorphological evidences have suggested that the Himalayan uplift began in the Tethys Himalaya, which is situated to the north of the present crest line of the Higher Himalaya in the Miocene; the uplift then shifted southward with time and was finally accelerated in the Higher Himalaya since the Late Pliocene (Arita and Ganzawa 1997). Such a southward migration of the uplift process through time is attributed principally to the southward shifting of a series of the thrusts splays from the décollement. Radiometric age data indicate that the Higher Himalaya has uplifted more rapidly since the Late Pliocene. The fission-tack age data, however, show that the recent rapid uplift of the Higher Himalaya $(6 \mathrm{~mm} / \mathrm{y}$ during the last $1.2 \mathrm{ma}$ ) is not related with the activity of the Main Central Thrust zone but is most likely caused by activity of the out-of-sequence thrusting (Arita and Ganzawa 1997, Arita et al. 1997).

In central Nepal the Kathmandu nappe consisting of the Higher Himalayan crystallines and the overlying Tethyan sediments extends southward covering the Lesser Himalayan sediments and forming a reverse $\Omega$ shape. An out-of-sequence thrust cuts the Higher Himalayan crystallines and the underlying Main Central Thrust zone in a narrow part to the north of Kathmandu basin (Figure 1). The Gosainkund Lekh (range) of nearly 5, $500 \mathrm{~m}$ in altitude between the out-ofsequence thrust and the Langtang Valley in the north is composed mainly of sillimanite-kyanite-garnet gneisses and granitic gneisses of the Higher Himalayan crystallines. We did fission-track dating on zircons from nine samples of these gneisses (Figure 1). The ages range from 1.5 $\pm 0.1 \mathrm{Ma}(1,525 \mathrm{~m}$ in elevation) to $2.8 \pm 0.2 \mathrm{Ma}(5,045 \mathrm{~m})$ (Figure 2) and they are almost similar to those from the Annapurna area (1.2 Ma to 2.3 Ma: Arita and Ganzawa 1997). One of the samples dated comes from mylonitic augen gneiss in the Main Central Thrust zone (no.9 in Figure 1) which is equivalent to so-called Ulleri-type augen gneiss in the Annapurna area of central Nepal. The relationship between ages and elevations of sampled locality shows notable contrast between the northern slope and the southern slope of the Gosainkund Lekh. The ages of samples from the northern side increase linearly with increase in the elevation of sampled sites and show an average exhumation rate of $2.7 \mathrm{~mm} / \mathrm{y}$. This rate is significantly higher than that in the Annapurna area $(0.9 \mathrm{~mm} / \mathrm{y})$. On the other hand, southern side yields almost identical ages between $2.5 \pm 0.2 \mathrm{Ma}$ and $2.8 \pm 0.2 \mathrm{Ma}$ regardless of sample elevation despite the large distance covered by the samples 1 to 6 (Figure 2).

These data suggest that the rocks on the southern side of the Gasainkund Lekh passed evenly the depth of closure temperature of zircon around 2.6 Ma, and then the northern part of the southern side (the highest part of the Gosainkund Lekh) and the northern side uplifted more rapidly and steadily than the southern part. The uplift of the area from the highest part of the Gosainkund Lekh northward resulted probably from the subsurface antiformal structure due to ramping in a depth caused by northward advancement of the Indian mid-crustal wedge sandwiched between the overlying out-of-sequence thrust and the underlying Main Detachment Fault (Figure 3).

As shown in Figure 2 samples 6 to 9 plot linearly although the Upper Main Central Thrust is located between samples 8 and 9. This suggests that the Upper Main Central Thrust has been inactive from 1.5 Ma onward. Takagi et al. (2003) observed that a northeastward brittle extensional movement of the Main Central Thrust zone overprinted the southward ductile thrust

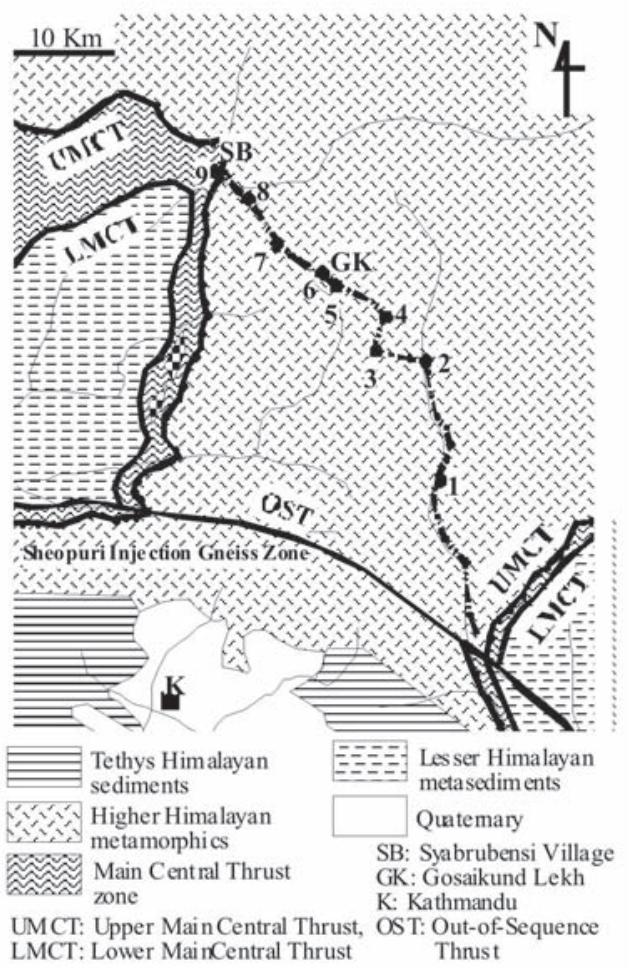

FIGURE 1. Geological division of the Gosaikund Lekh area in central Nepal and sample localities (1-9) for fission-tack dating 
movement in the Syabrubensi area (SB in Figure 1). They assumed the age of the northward normal faulting to be 3-2 Ma. Hence, our data are consistent with their interpretation.

\section{References}

Arita K and Y Ganzawa. 1997. Thrust tectonics and uplift of the Nepal Himalaya revealed from Fission-track ages. Journal of Geography 106(2): 156-167

Arita K, RD Dallmeyer and A Takasu. 1997. Tectonothermal volution of the Lesser Himalaya, Nepal: constraints from ${ }^{40} \mathrm{Ar} /{ }^{39} \mathrm{Ar}$ ages from the Ka from the Kathmandu nappe. The Island Arc 6: 372-384

Schelling D and K Arita. 1991. Thrust tectonics, crustal shortening, and the structure of the far-eastern Nepal Himalaya. Tectonics 10: 851-862

Takagi H, K Arita, T Sawaguchi, K Kobayashi and D Awaji. 2003. Kinematic history of the Main Central Thrust zone in the Langtang area, Nepal. Tectonophysics 366: 151-163

Zhao WJ, KD Nelson and Project INDEPTH Team. 1993. Deep seismic reflection evidence for continental underthrusting beneath southern Tibet. Nature 366: 557-559

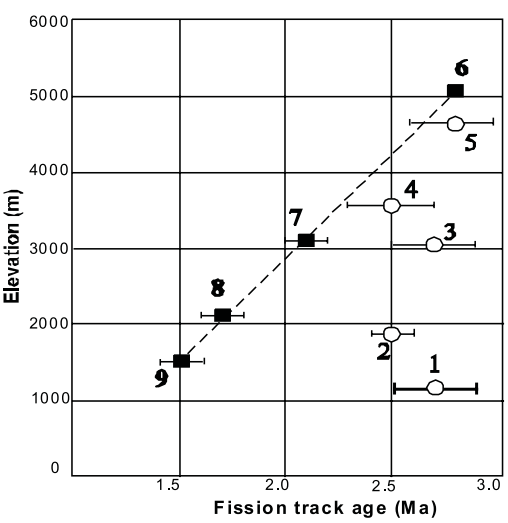

FIGURE 2. Relationship between fission track age and sample elevation. Sample localities are shown in Figure 1

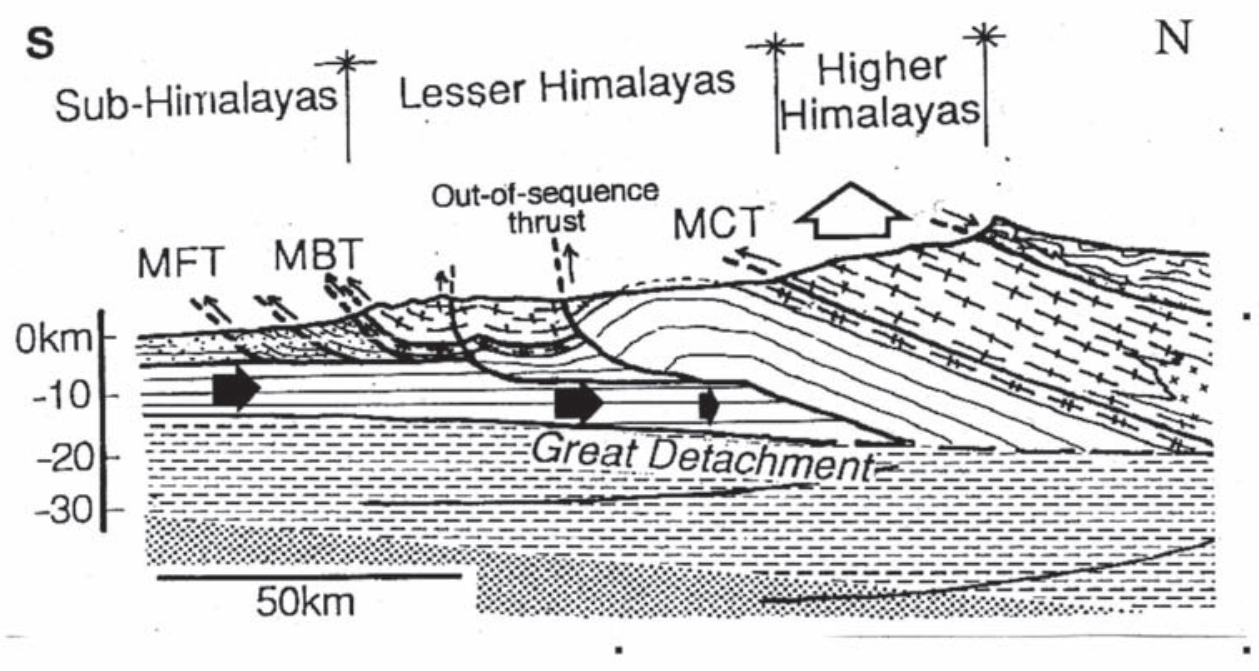

FIGURE 3. Schematic cross-section of the Nepal Himalaya showing recent rapid uplift of the area north of the out-of-sequence thrust (Higher Himalaya) caused by ramping of the thrust and the resultant crustal antiform due to rushing of brittle Indian mid-crustal wedge 